\title{
Gentle Nudges vs. Hard Shoves: Solving the Sticky Norms Problem
}

\author{
Dan M. Kahan $\dagger$
}

\begin{abstract}
The resistance of law enforcers sometimes confounds the efforts of lawmakers to change social norms. Thus, as legislators expand liability for date rape, domestic violence, and drunk driving, police become less likely to arrest, prosecutors to charge, jurors to convict, and judges to sentence severely. The conspicuous resistance of these decisionmakers in turn reinforces the norms that lawmakers intended to change. Can this "sticky norms" pathology be effectively treated? It can be, this Article argues, if lawmakers apply "gentle nudges" rather than "hard shoves" When the law embodies a relatively mild degree of condemnation, the desire of most decisionmakers to discharge their civic duties will override their reluctance to enforce a law that attacks a widespread social norm. The willingness of most decisionmakers to enforce can initiate a self-reinforcing wave of condemnation, thereby allowing lawmakers to increase the severity of the law in the future without prompting resistance from most decisionmakers. The paper presents a formal model of this strategy for norm reform, illustrates it with real world examples, and identifies its normative and prescriptive implications.
\end{abstract}

My concern in this Article is with the "sticky norms problem." This problem occurs when the prevalence of a social norm makes decisionmakers reluctant to carry out a law intended to change that norm.

This is a familiar pathology. To change the behavior of men (and women) who have internalized the norm that "no sometimes means yes," some states have modified their rape laws either to dispense with the common law element of force or to eliminate the "reasonable mistake of fact" defense with respect to consent. Empirical studies suggest, however, that such reforms have little effect on juries, which continue to treat verbal resistance as equivocal evidence of nonconsent, or on prosecutors, who remain reluctant to press charges unless the victim physically resisted the man's advances.'

The same story can be told about attempts to crack down on drunk driving and domestic violence. As states adopt more severe laws, police grow more reluctant to arrest, prosecutors to charge, juries

$\dagger$ Professor, Yale Law School. I'm grateful to Yale Law School for funding the research reflected in this Article; to Jack Balkin, Kenworthey Bilz, John Lott, and Reva Siegel for help in formulating the argument; to Bruce Ackerman, Ian Ayres, Katharine Baker, Dov Cohen, Herb Gintis, Douglas Husak, George Loewenstein, Alvin Klevorick, Tracey Meares, Eric Posner, Roberta Romano, and Susan Rose Ackerman for comments; to workshop participants at Fordham Law School, the University of California School of Law at Berkeley, and Yale Law School for constructive criticism and suggestions; and to Brian Lehman, Christine Lehmann, Sarah Olson, and Brian Willen for research assistance.

1 For a general discussion, see Stephen J. Schulhofer, Unwanted Sex: The Culture of Intimidation and the Failure of Law ch 2 (Harvard 1998). 
to convict, and judges to punish. ${ }^{2}$ As a result, such reforms do nothing to reduce the incidence of these offenses.

Indeed, they may even increase the incidence of such crimes. For example, when a jury in a high profile case acquits a defendant charged with raping a woman who protested but who didn't physically resist his advances, the verdict reaffirms the vitality of the norm that "no sometimes means yes," and thus perpetuates behavior consistent with the norm. ${ }^{3}$

Some might conclude from the "sticky norms problem" that the law is a relatively ineffective instrument for changing norms. ${ }^{4} \mathrm{I}$ believe, however, that the problem of sticky norms reflects the primitive state of our understanding of how laws and norms interact. I want to suggest a more realistic account, one that should help reformers see how the law can be used to make sticky norms come unstuck.

The decisive factor in determining whether a norm will inhibit enforcement, I will argue, is how much more severely the law condemns the behavior than does the typical decisionmaker. If the law condemns the conduct substantially more than does the typical decisionmaker, the decisionmaker's personal aversion to condemning too severely will dominate her inclination to enforce the law, and she will balk. Her reluctance to enforce, moreover, will strengthen the resistance of other decisionmakers, whose reluctance will steel the resolve of still others, triggering a self-reinforcing wave of resistance.

If, however, the law condemns the behavior only slightly more than does the typical decisionmaker, her desire to discharge her civic duties will override her reluctance to condemn, and she will enforce the law. Her willingness to enforce will now strengthen the willingness of other decisionmakers to enforce, which will in turn reinforce the inclination of still others to do the same. In the resulting wave of condemnation, lawmakers will be able to increase the degree of condemnation reflected in the law without prompting resistance from most decisionmakers.

In short, norms stick when lawmakers try to change them with "hard shoves" but yield when lawmakers apply "gentle nudges." I will develop this argument in three steps. In Part I, I present a (semi-) formal model of the "gentle nudges/hard shoves" dynamic. In Part II, I

2 See H. Laurence Ross, Confronting Drunk Driving: Social Policy for Saving Lives 56-58 (Yale 1992); Joan Zorza, The Criminal Law of Misdemeanor Domestic Violence, 1970-1990, 83 J Crim L \& Criminol 46, 65 (1992).

3 See Schulhofer, Unwanted Sex at 258 (cited in note 1).

4 See, for example, Angela P. Harris, Forcible Rape, Date Rape, and Communicative Sexuality: A Legal Perspective, in Leslie Francis, ed, Date Rape: Feminism, Philosophy, and the Law 61 (Penn State 1996). 
illustrate the model with a collection of real world examples. And in Part III, I draw some normative and prescriptive conclusions.

\section{THE MODEL}

Imagine a society whose members are divided about how to regard some form of behavior that reflects a contested social norm. Many regard the behavior as perfectly appropriate or as at most a trifling wrong. Others vehemently denounce it and demand that it be severely sanctioned, both to deter individuals from engaging in it and to change the social norm that gives rise to it. A significant group of citizens falls somewhere in between. Against the will of those who condone the behavior, those intent on denouncing it prevail in obtaining legislation that prohibits the behavior or, assuming it is already subject to modest regulation, substantially raises the penalty for it.

What will happen next? That depends, I will argue, on exactly how severely the new law condemns the behavior relative to the sensibilities of the decisionmakers who are called upon to enforce it. If the law condemns too severely -if it tries to break the grip of the contested norm (and the will of its supporters) with a "hard shove"-it will likely prove a dead letter and could even backfire. If it condemns more mildly - if it "gently nudges" citizens toward the desired behavior and attitudes-it might well initiate a process that culminates in the near eradication of the contested norm and the associated types of behavior. This Part describes the behavioral dynamics underlying this claim.

\section{A. Gentle Nudges vs. Hard Shoves}

The relationship I want to establish between norms and law is illustrated by Figure 1: 
FIGURE 1

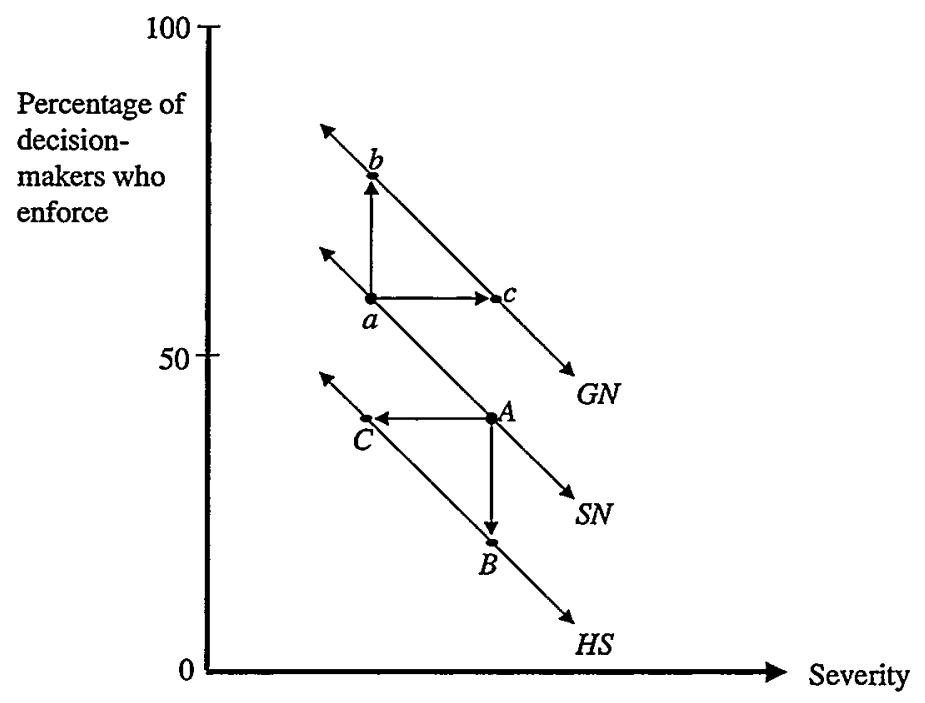

The downward slope of the curve $S N$ represents the sticky norms problem. As severity of condemnation-measured by the breadth of the statutory prohibition, the size of the penalty, or the strictness of centrally imposed enforcement guidelines-increases, the percentage of decisionmakers who are willing to enforce the law declines. If the lawmaker selects a sufficiently severe degree of condemnation-point $A$ on the $S N$ curve-then a majority of decisionmakers will in fact resist enforcement.

This condition reinforces itself. As members of society observe that most decisionmakers are unwilling to enforce the law, the norm that the law is designed to change will grow in strength. As a result, the resistance of decisionmakers will grow too. If the law remains unchanged, the percentage of decisionmakers willing to enforce it will shift downward from point $A$ to point $B$. Alternatively, if the lawmaker wants to avoid erosion in enforcement, she will have to reduce the severity of condemnation to point $C$. The result of the initial "hard shove" is a new, even less condemnatory relationship between severity and enforcement levels, as reflected in the curve $H S$.

The dynamic is reversed, however, when the lawmaker starts out with a "gentle nudge." If the lawmaker selects a sufficiently mild de- 
gree of severity-point $a$ on the $S N$ curve-then a majority of decisionmakers will enforce the law at the outset. This condition, too, will reinforce itself. As members of society are exposed to consistent and conspicuous instances of enforcement, they will revise upward their judgment of the degree of condemnation warranted by the conduct in question. Accordingly, over time, the percentage of decisionmakers willing to enforce the existing law will grow-from point $a$ to point $b$. Alternatively, without dissipation of enforcement levels, the lawmaker will be free to increase the severity of condemnation reflected in the law to point $c$. The result is a new, more condemnatory equilibrium, as represented in the curve $G N$.

\section{B. Enforcement Utility Function}

The "hard shove/gentle nudge" dynamics illustrated in Figure 1 represent the effect of severity on enforcement decisions in the aggregate. I now want to relate these dynamics to a psychologically and behaviorally realistic model of enforcement decisionmaking at the individual level.

In this model, we can represent the enforcement propensity of an individual decisionmaker, $i$, as a utility function. For this purpose, $i$ could be a police officer, a prosecutor, a juror, or a judge. Indeed she could even be a private citizen deciding whether to enforce the law informally by stigmatizing lawbreakers. The utility $i$ gets from enforcing is the sum of three variables: $P_{i}$, which represents $i$ 's personal opinion of how severely the particular conduct in question should be condemned; $L_{i}$, which represents $i$ 's commitment to discharging her civic duties in general; and $G_{i}$, which represents $i$ 's propensity to conform her enforcement decisions to the decisions of other decisionmakers considered as a group. When $P_{i}+L_{i}+G_{i}>0, i$ enforces the law. When $P_{i}+L_{i}+G_{i}<0$, she balks.

Figure 2 illustrates how each variable in $i$ 's enforcement utility function influences $i$, and how the three of them interact, individually and collectively, with condemnation severity. 
FIGURE 2

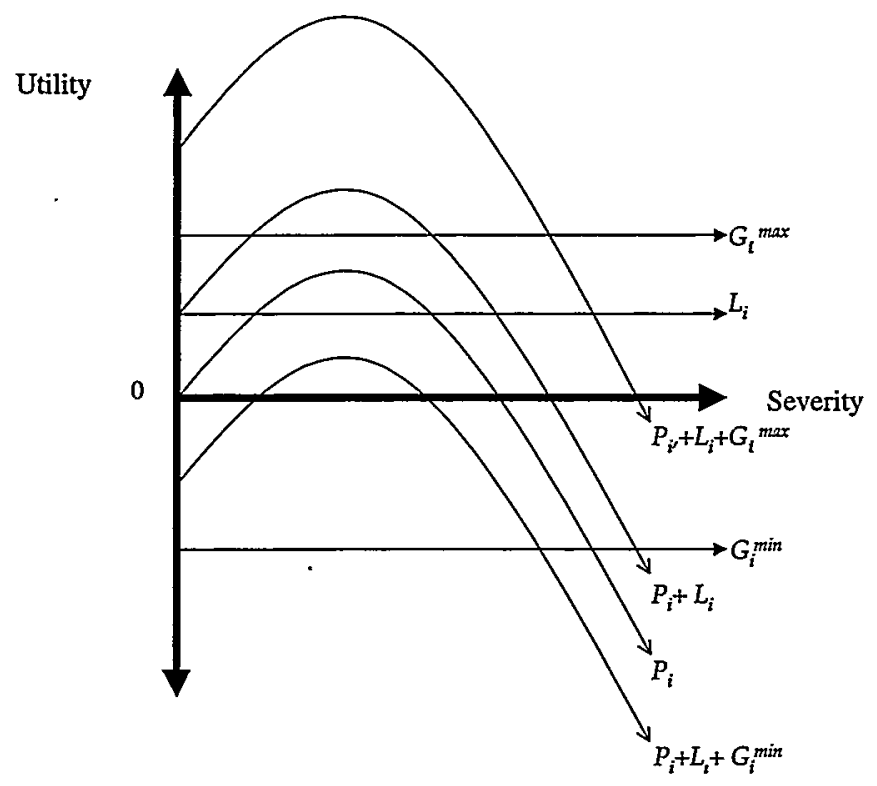

The curve $P_{i}$ represents the contribution that $i$ 's personal evaluation of the conduct makes to her willingness to enforce. As the severity of condemnation moves from 0 toward what $i$ personally regards as appropriate, the value of $P_{i}$ increases; as severity exceeds what she personally regards as appropriate, the value of $P_{i}$ decreases, and at some point becomes negative, at which point she declines to enforce. This relationship is consistent with empirical evidence that shows that individuals have a taste for punishing others who violate norms, prefer to reward those who behave consistently with norms, and favor proportionate over disproportionate sanctions when punishment is due. ${ }^{5}$

Empirical evidence also shows that, all else equal, individuals prefer to carry out their legal obligations. Relative to other influences, the status of conduct as legal or illegal, for example, has a significant, al-

5 Such evidence includes the already vast and growing body of experimental research on reciprocal behavior. For general discussions, see Ernst Fehr and Simon Gächter, Cooperation and Punishment in Public Goods Experiments: Evidence from Switzerland, 90 Am Econ Rev (forthcoming Sept 2000); Armin Falk, Ernst Fehr, and Urs Fischbacher, Why do People Punish? Testing Theories of Fairness (unpublished manuscript, Dec 5, 1999); Gary Charness and Matthew Rabin, Social Preferences: Some Simple Tests and a New Model (unpublished manuscript, Jan 2000); Armin Falk and Urs Fischbacher, $A$ Theory of Reciprocity (unpublished manuscript, Feb 1999). That $P_{1}$ displays the precise shape reflected in Figure 2 is, of course, a simplifying assumption. The only critical feature of the shape of $P_{t}$ is that it is single peaked. 
beit modest, impact on an individual's moral appraisal of that conduct. ${ }^{6}$ Curve $L_{i}$ signifies that $i$ 's general commitment to carrying out her obligations makes a uniform contribution to $i$ 's utility across varying levels of condemnation severity.

The curve $P_{i}+L_{i}$ shows how $i$ 's personal degree of condemnation and her preference to discharge her legal obligations interact. The utility that $i$ derives from discharging her legal duties augments the personal satisfaction she takes in condemning it. Accordingly, the value of $P_{i}+L_{i}$ is greater than the value of $P_{i}$ at any given level of severity. As severity exceeds the level that $i$ personally views as optimal, the value of $P_{i}+L_{i}$ declines and eventually becomes negative, triggering nonenforcment. Nevertheless, because $P_{i}$ and $L_{i}$ are additive, there is a range of severity levels over which $P_{i}$ is negative but $P_{i}+L_{i}$ is positive. In other words, $i$ 's desire to discharge her duties makes her willing to enforce a law that she personally regards as unduly condemnatory, although only up to a point.

She is also willing to conform her enforcement decision to the choices of other decisionmakers up to a point, as represented by the $G_{i}$ variable in $i$ 's enforcement utility function. The tendency of individuals to conform - a phenomenon psychologists call "social influence" they think other diners will patronize, and citizens to vote for the candidates for whom they think others will vote; teenage girls are more likely to become pregnant when they see that others are having babies, ${ }^{10}$ and adults more likely to go on welfare when they become acquainted with others who are on the dole."

6 See, for example, Nigel Walker and Catherine Marsh, Do Sentences Affect Public Disapproval?,24 Brit J Criminol 27,38-39 (1984) (reporting that survey respondents were more likely to disapprove of "seat belt non-use" when it was illegal than when it was not); Nigel Walker and Michael Argyle, Does the Law Affect Moral Judgments?, 4 Brit J Criminol 570, 574-75 (1963) (reporting that some survey respondents who did not consider heavy smoking morally wrong said they would change their view if Parliament passed a law making smoking a criminal offense).

7 See Elliot Aronson, The Social Animal 6-7 (W.H. Freeman 7th ed 1995). See also Dan M. Kahan, Social Influence, Social Meaning, and Deterrence, 83 Va L Rev 349 (1997) (discussing significance of social influence for deterrence theory in criminal law).

8 See, for example, Gary S. Becker, A Note on Restaurant Pricing and Other Examples of Social Influences on Prices, $99 \mathrm{~J}$ Pol Econ 1109 (1991).

9 See, for example, Larry M. Bartels, Expectations and Preferences in Presidential Nominating Campaigns, 79 Am Pol Sci Rev 804 (1985).

10 See, for example, George A. Akerlof, Janet L. Yellen, and Michael L. Katz, An Analysis of Out-of-Wedlock Childbearing in the United States, 111 Q J Econ 277 (1996).

11 See Marianne Bertrand, Erzo F.P. Luttmer, and Sendhil Mullainathan, Network Effects and Welfare Cultures (unpublished manuscript, Apr 9, 1998). 
Individuals are also more likely to view conduct as worthy of condemnation when they know that others condemn it. ${ }^{12}$ Indeed, studies suggest that the opinions of one's peers more significantly influence one's moral attitudes toward various forms of conduct than does the status of those forms of conduct under the law. ${ }^{13}$ This is not surprising. In a society in which highly organized and intensely interested minorities exercise disproportionate influence over lawmakers, citizens won't automatically infer that the law represents widespread moral consensus. They are likely to form that impression only if they observe their associates complying with, enforcing, or speaking well of the law. ${ }^{14}$

Social influence effects can be especially intense when decisionmakers engage in discussions with one another. The phenomenon of "group polarization" refers to the tendency of deliberating individuals to migrate toward the extremes rather than the middle. If opinion within a group starts out as only modestly weighted toward one position or another on some factual or evaluative issue, it is likely to end up decidedly skewed toward that position as individuals learn how others feel and why. ${ }^{15}$ Convincing experimental and empirical data suggest that "group polarization" looms large in behavior of juries" and judges. ${ }^{17}$ It is plausible to believe that the same dynamic affects the opinions of other types of decisionmakers as well-from police offi-

12 See, for example, Robert B. Cialdini, Social Motivations to Comply: Norms, Values, and Principles, in Jeffery A. Roth and John T. Scholz, eds, 2 Taxpayer Compliance 213-14 (Pennsylvania 1989).

13 See Harold G. Grasmick and Donald E. Green, Legal Punishment, Social Disapproval and Internalization as Inhibitors of Illegal Behavior, 71 Crim L \& Criminol 325 (1980) (finding peer views have bigger impact on decision to obey law than does assessment of legal penalties). See also Walker and Marsh, 24 Brit J Criminol at 37-39 (cited in note 6) (suggesting both peer disapproval and the legal status of conduct affect people's attitudes); Walker and Argyle, 4 Brit $J$ Criminol at 574-75 (cited in note 6) (same).

14 See, for example, Marco R. Steenbergen, Kathleen M. McGraw, and John T. Scholz, Taxpayer Adaptation to the 1986 Tax Reform Act: Do New Tax Laws Affect the Way Taxpayers Think About Taxes?, in Joel Slemrod, ed, Why People Pay Taxes? Tax Compliance and Enforcement 2930 (Michigan 1992) (finding that individuals conform assessments of tax law to those of peers). For an empirical demonstration of the power of social influence on legal decisionmakers, see Richard L. Revesz, Environmental Regulation, Ideology, and the D.C. Circuit, 83 Va L Rev 1717 (1997). Revesz finds that the ideological disposition of the other judges with whom an individual judge sits on a three-judge panel exerts more influence on the individual judge's vote in an environmental case than does that judge's personal ideology. Id at 1719.

15 See Cass R. Sunstein, Deliberative Trouble? Why Groups Go to Extremes, 110 Yale L J (forthcoming 2000).

16 See David Schkade, Cass R. Sunstein, and Daniel Kahneman, Deliberating About Dollars: The Severity Shift, 100 Colum L Rev (forthcoming 2000).

17 See Revesz, 83 Va L Rev 1717 (cited in note 14). See also Frank B. Cross and Emerson H. Tiller, Judicial Partisanship and Obedience to Legal Doctrine: Whistleblowing in the Federal Courts of Appeal, 107 Yale L J 2155 (1998). 
cers to prosecutors to private citizens-as they compare views on whether a particular law warrants aggressive or only lax enforcement.

Thus, we can treat the perceived disposition of others to enforce a law as adding to the utility that $i$ gets from enforcing. What it adds will depend on what other decisionmakers are doing. If a relatively high percentage are enforcing, then the $G_{i}$ argument in $i$ 's enforcement utility function will have a high positive value, as represented by the curve $G_{i}^{\max }$. At that point, $i$ 's disposition to enforce is at its maximum. Even when she personally regards the law as substantially too severe, $i$ will be willing to enforce it because of the combined effect of her desire to discharge her duties and her amenability to the influence of her peers. This effect is represented by the curve $P_{i}+L_{i}+G_{i}^{\max }$, which remains positive over a significant range of severity values for which $P_{i}$ is negative.

Alternatively, if a relatively high percentage of decisionmakers are not enforcing, then $G_{i}$ will have a high negative value, as represented by the curve $G_{i}^{\text {min }}$. At that point, $i$ 's disposition to enforce is at its minimum. Notwithstanding both her personal opinion that conduct is worthy of condemnation and her desire to carry out her legal duties, the conspicuous resistance of her fellow decisionmakers will stifle $i$ 's willingness to enforce the law. This effect is represented by the curve $P_{i}+L_{i}+G_{i}^{\text {min }}$, which remains negative over a substantial range of severity values for which both $P_{i}$ and $P_{i}+L_{i}$ are positive.

Of course, the percentage of decisionmakers enforcing the law might be neither high nor low but rather somewhere in between. In that case, the contribution that $G_{i}$ will make to $i$ 's enforcement utility will be correspondingly less dramatic.

The effect that social influence has on the disposition of an individual decisionmaker to enforce the law, moreover, adds dynamism to the aggregate behavior of decisionmakers over time. This is so because behavior shaped by social influence is subject to feedback effects. ${ }^{18}$ When an individual perceives that a relatively large group of likesituated persons are engaging in a certain form of behavior, she is more likely to engage in that behavior, too; this increases the size of the group, inducing even more individuals to engage in the behavior, and so forth and so on. By the same token, when an individual perceives that the group of individuals engaging in a behavior is relatively

18 See Randal C. Picker, Simple Games in a Complex World: A Generative Approach to the Adoption of Norms, 64 U Chi L Rev 1225 (1997) (developing formal model of tipping points and feedback effects); Thomas C. Schelling, Micromotives and Macrobehavior 50 (Norton 1978) (same). I am indebted to Susan Rose-Ackerman for helping me to clarify this aspect of the model. 
small, she is likely to cease engaging in the behavior; that reduces the size of the group, thereby inducing even more individuals to refrain from the behavior, and so forth and so on.

This dynamic is illustrated in Figure 3, which treats the percentage of decisionmakers who will enforce in the next period, $t_{n+1}$, as a function of the percentage who enforce in this one, $t_{n}$.

\section{FIGURE 3}

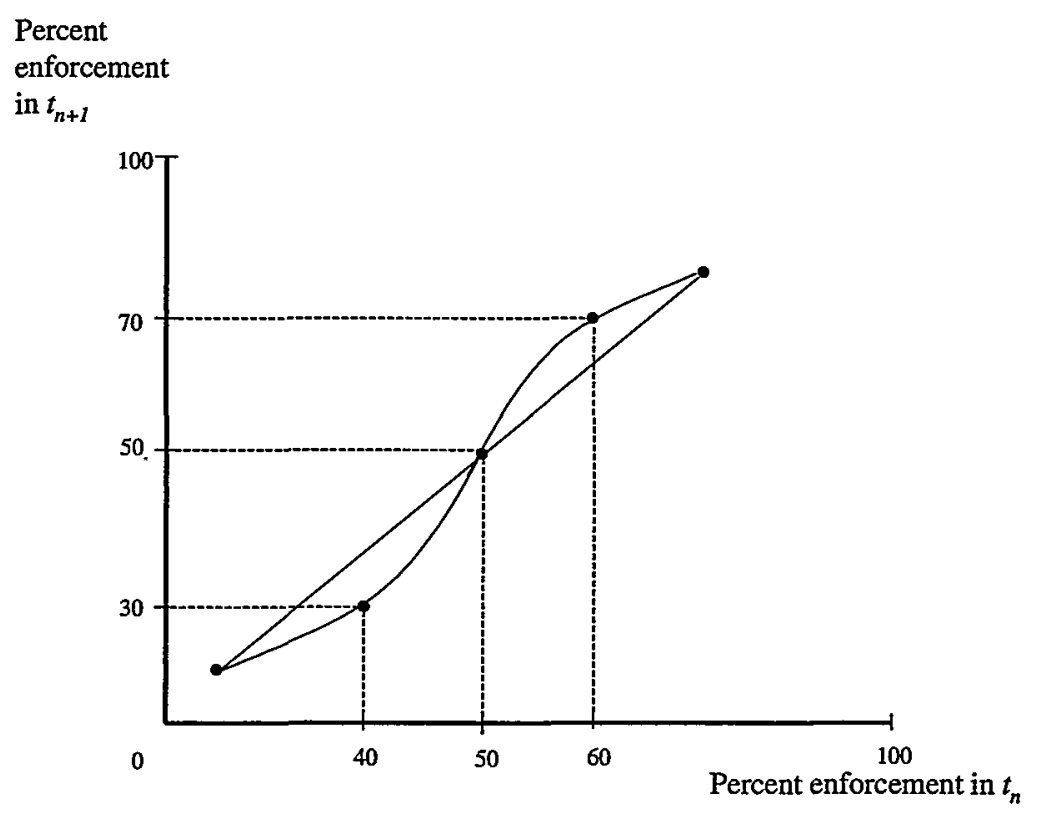

In this particular representation, there are three enforcementlevel equilibria. One is around 50 percent: if decisionmakers in $t_{n}$ perceive that about half of the other decisionmakers are enforcing, then about half will choose to enforce in $t_{n+1}$, which means that about that many will enforce in $t_{n+2}$, and so forth and so on. But this middle equilibrium is relatively fragile. If as a result of some exogenous shock, more than 50 percent are induced to enforce in $t_{n}$ (say, 60 percent), then an even higher percentage than that will be willing to enforce in $t_{n+1}$ (70 percent), leading to a still higher percentage in $t_{n+2}$, and so forth and so on until enforcement levels top out at the equilibrium at the upper right hand corner. Similarly, if for some reason less than 50 percent enforce in $t_{n}$ (say, 40 percent) then an even smaller percentage will enforce in $t_{n+1}$ (30 percent), leading to a lower enforcement level in $t_{n+2}$, and so forth and so on until enforcement levels bottom out at the 
equilibrium on the lower left hand corner. The corner equilibria, moreover, are relatively durable: exogenous shocks may result in temporary boosts or drops in enforcement but unless they are big enough to push the enforcement level back across the 50 percent tipping point, the enforcement level will quickly settle back into the corner equilibrium from which it started."

The relationships illustrated in Figures 2 and 3 entail the dynamics illustrated in Figure 1. Assume $i$ is the median decisionmaker with respect to enforcement utility at any level of severity. ${ }^{20}$ Assume further (as seems reasonable) that decisionmakers are relatively heterogeneous with respect to $P_{i}$-that is, with respect to their personal opinions about the moral quality of the underlying conduct-but relatively homogeneous with respect to $L_{i}$ and $G_{i}$-that is, with respect to their desire to carry out their duties and their amenability to group influence. If in period 1-when group influence can be assumed to be negligible ${ }^{21}$ the lawmaker selects a severity level that generates a negative value for $P_{i}+L_{i}, i$, along with a majority of decisionmakers, will decline to enforce the law. Because most decisionmakers are resisting enforcement, $G_{i}$ in the next period will be negative for all decisionmakers. ${ }^{22}$ Accordingly, even fewer decisionmakers will now be willing to enforce. That will drive $G_{i}$ even further down in subsequent periods, further depressing enforcement, and so forth and so on until $G_{i}$

19 The enforcement levels at the corner equilibria have been selected arbitrarily for purposes of illustration. In real life, those levels will depend on how severely the law condemns: as severity increases the minimum and maximum percentages of decisionmakers willing to enforce will shift because enforcement decisions are a function not only of $G_{i}$ but also of $P_{i}$. See Figure 2 .

20 Insofar as jury verdicts in criminal cases ordinarily must be unanimous, the assent of the median juror to a particular rule won't necessarily assure that the majority of juries will assent to the rule. The analysis holds, however, if we assume that $i$ is the median jury, rather than the median juror, in cases in which the jury is the relevant decisionmaker.

21 This is another simplifying assumption. By virtue of the circumstances surrounding the adoption of a new law, for example, decisionmakers might initially expect enforcement to be either high or low. In that case, the severity of condemnation reflected in the new law will be less dramatic in determining how receptive decisionmakers will be to enforcing the law, either immediately or over time. Of course, the circumstance that is most likely to inform an individual decisionmaker's expectation about initial enforcement levels is her perception that other decisionmakers view the new law as either tolerably or unduly severe. In that situation, decisionmakers behave as the text suggests, except that in the first period they act as if they were exposed to information about a previous period in which enforcement was either high or low.

22 This conclusion assumes, for simplicity, that social influence makes a positive or negative contribution to a decisionmaker's enforcement utility depending on her perception of what most decisionmakers are doing. The analysis doesn't depend on this assumption, however. In some domains, we might expect individual decisionmakers to be disproportionately influenced by what particular subgroups of decisionmakers (perhaps those who are most conspicuous, or those with whom she identifies on social or other grounds) are doing. In that case, we should think of $i$ as a strategically placed "swing decisionmaker." It would then be that decisionmaker's respective responses to "gentle nudges" and "hard shoves" that generate the dynamics in Figure 1. 
reaches the minimum equilibrium state represented by $G_{i}^{\min }$, and enforcement drops off to a correspondingly low level.

In this circumstance, then, the percentage of decisionmakers willing to enforce the law at any level of severity will be dropping over time. This is the condition represented in Figure 1 by the leftward shift from $S N$ to $H S$. The lawmaker's "hard shove" defeats itself.

Now imagine, in contrast, that the lawmaker in the first period selects a severity level that generates a positive value for $P_{i}+L_{i}$. In that circumstance, $i$, along with a majority of decisionmakers, will enforce the law. Because most decisionmakers are now enforcing, $G_{i}$ will be positive in the next period. At that point, an even greater percentage of decisionmakers will derive positive utility from enforcement, and hence choose to enforce the law. $G_{i}$ will therefore be even higher in the next period, and so forth and so on until $G_{i}$ reaches the maximum equilibrium state represented by $G_{i}^{\max }$, and enforcement plateaus at a correspondingly high level.

The percentage of decisionmakers willing to enforce the law at any level of severity will now be increasing over time. As represented in Figure 1, there will be a shift from $S N$ to $G N$. For the moderation reflected in her "gentle nudge," the lawmaker is rewarded with a population of maximally condemnatory enforcers. ${ }^{23}$

Maximally, but of course not infinitely. As $G_{i}$ increases and ultimately plateaus at $G_{i}^{\max }$, the lawmaker will be able substantially to increase the penalty without alienating enforcers. Consistent with Figure 3 , each increase in severity will cause only a temporary drop off in the enforcement level, which will quickly bounce back to the far right equilibrium. But if an increase in severity is ever so dramatic that it drives enforcement below 50 percent, then the drop off will not be temporary but will (consistent with Figure 3) spiral downwards until it settles down into the far left equilibrium. At that point, the lawmaker will be forced to reduce severity - substantially-in order to restore an adequate enforcement level. The risk that any increase in severity will produce such a shift, moreover, increases as absolute severity rises, insofar as the utility that the median decisionmaker derives from enforcement approaches zero as severity increases, even when $G_{i}$ is at its maximum value (see Figure 2). In sum, there are limits beyond which even the norm-savvy lawmaker cannot push enforcers without triggering a decisive backlash.

23 In the context of this illustration, then, a "gentle nudge" is any upward adjustment in severity mild enough to attain the assent of the median decisionmaker, and a "hard shove" any adjustment severe enough to provoke resistance from the median decisionmaker. 
C. Clarifications and Qualifications

1. Deterrence.

The model I have described generates the admittedly counterintuitive conclusion that less condemnatory laws ("gentle nudges") are sometimes more effective in changing norm-driven behavior than are more condemnatory ones ("hard shoves"). I don't, however, mean to be challenging the conventional economic premise that the level of crime varies inversely with the expected penalty for it. $^{24}$ Indeed, my analysis assumes that this proposition is basically correct. On the conventional analysis, however, the expected penalty is the product of the severity of a punishment and the probability it will be imposed. ${ }^{25}$ If as a result of the "hard shove" dynamic, decisionmakers balk at enforcing an overly condemnatory law, the drop in the probability of punishment might well dwarf the severity of it, resulting in less deterrence on net. Indeed, this effect is magnified if one accepts that enforcement levels make a significant contribution to the formation of individuals' preferences to engage in criminality. ${ }^{26}$ To the extent that enforcement levels matter for these or other reasons, my model posits that lawmakers should, in some circumstances, avoid dramatic short-term increases in severity of punishment and instead raise penalties in modest increments over longer periods of time.

\section{Scope of the model.}

The model I have outlined predicts that a "gentle nudge" will dominate a "hard shove" when lawmakers try to change a norm that some members of society support, that others oppose, and that still others are ambivalent toward. These conditions are important but do not exhaust the circumstances in which norms become the object of legal regulation.

There are two additional sets of circumstances, in particular, in which "hard shoves" are unlikely to confound lawmakers' normreform objectives. One is where there is widespread consensus against the norm that the law is trying to change or suppress. If the vast majority of citizens are repulsed with pedophilia, there's no reason to suppose that decisionmakers will balk when lawmakers single out such conduct for severe condemnation. And even if lawmakers do

24 See Gary S. Becker, Crime and Punishment: An Economic Approach, $76 \mathrm{~J}$ Pol Econ 169, 183-84 (1968).

25 See id; Jeremy Bentham, The Principles of Morals and Legislation 179, 184 (Hafner Press 1948) (originally published in 1823).

26 See Kahan, 83 Va L Rev at 378-82 (cited in note 7). 
manage to overreach, the reluctance of decisionmakers to enforce disproportionately condemnatory laws against such conduct is unlikely to provoke a general reevaluation of the underlying norm. ${ }^{27}$

Another circumstance in which "hard shoves" are unlikely to be self-defeating is where dissensus about a norm radically polarizes society. In that case, a severely condemnatory law is unlikely to initiate any significant change in public attitudes, at least in the short term. Members of society who favor the targeted norm will resent the new law and will be reinforced in their disposition by the resentment of others who feel the same way. Likewise, members of society who oppose that norm will favor the law and will find confirmation of their attitudes in their peers' positive evaluation of it. And if the latter group is able to direct enforcement power to decisionmakers who share their commitments, they might well be able to force the desired behavior on the resistant minority - which over time might adapt its preferences to fit the law, although through mechanisms different from the ones I'm focusing on here.

27 The situation might be different, though, where a law that vindicates a widely shared norm in general intersects a contested norm in a particular case. Consider the case of Bernhard Goetz, the white New York City subway commuter who was acquitted of attempted murder after shooting four African-American teenagers who solicited him for cash. For a description of the case, see George P. Fletcher, A Crime of Self-Defense: Bernhard Goetz and the Law on Trial (Free Press 1988). That case generated immense controversy not because of dissensus surrounding homicide laws, but because of the volatile mix of racial tension and dissensus surrounding norms of violent self-help. See id at 18-19. Indeed, the jury's acceptance of Goetz's very shaky self-defense claim was interpreted by many as expressing and reinforcing public fear of, and animosity toward, young African-American men. See id at 203-08. That meaning, however, may well have been an artifact of the jury's resistance to the "hard shove" embodied in the attempted murder theory. Had the law recognized a "gentle nudge" alternative-say, a variant of "imperfect self-defense" that would have mitigated attempted murder to some lesser charge-the jury might well have convicted. And in that case, the verdict would likely have been interpreted as signaling at least moderate repudiation of racial animosity and violent self-help.

28 This might be an accurate description in general of the progress of anti-discrimination law, and in particular school desegregation, in America. Nevertheless, to at least some extent, the success of the 1964 Civil Rights Act might be attributable to the drafters' sensitivity to the perils of hard shoves. When Southern Senators, for example, argued-no doubt disingenuously - that existing criminal penalties were sufficient to assure compliance with the duty to desegregate schools, Attorney General Robert Kennedy replied:

In many places the idea of discrimination against a Negro is accepted, it is a way of life. Some people don't think it's a criminal act. To take criminal action against individuals whose fathers dealt with Negroes that way, who have been taught to deal with Negroes that way, whose State Governor says Negroes should be treated that way, and try to send him to jail, just is not going to work.

Quoted in James Dunn, Title VI, the Guidelines, and School Desegregation in the South, 53 Va $\mathrm{L}$ Rev 42, 49 n 30 (1967). Instead, Title VI of the Act imposed federal funding cutoffs, a remedy that was made progressively stricter over the course of the decade, and that is viewed as one of the primary causes of the success of school desegregation efforts. See Gerald N. Rosenberg, The Hollow Hope: Can Courts Bring About Social Change? 98-100 (1991); Michael Klarman, Brown, 
3. Preference change.

The model developed in this Part is designed to capture the endogeneity of decisionmakers' enforcement preferences. Although the model treats $i$ 's decision to enforce as a function of the utility she gets from factors in addition to her own "personal opinion" of the conduct $\left(P_{i}\right)$, it's more behaviorally and psychologically realistic to see the sum of all these factors as representing $i$ 's overall attitude toward the conduct in question. The point of including multiple variables in i's enforcement utility function is to show that decisionmakers' attitudes are not fixed but rather responsive to changing conditions and thus variable over time.

In the model as I have constructed it, what decisionmakers' enforcement preferences are endogenous to is social influence. The intensity with which individual decisionmakers condemn the conduct in question rises or falls as the proportion of decisionmakers willing to enforce the law rises or falls.

Social influence, however, is not the only mechanism capable of producing the shifting enforcement preferences represented in the model. The avoidance of "cognitive dissonance," for example, might predict a similar pattern. To avoid the discomfort associated with inconsistency, decisionmakers who relent to the enforcement of a law that they believe is slightly too condemnatory might over time adopt a more condemnatory attitude toward the behavior, and thereby become receptive to even more condemnatory laws. In these accounts, decisionmakers' enforcement preferences are endogenized not to the behavior of other decisionmakers but to their own behavior in the past.

I have chosen to focus on the mechanism of social influence rather than cognitive dissonance for several reasons. First, as the next Part should make clear, I believe the susceptibility of decisionmakers to group influences plays a more conspicuous role than this alternative mechanism in examples of legal reform characterized by "hard shove/gentle nudge" dynamics.

Second, a model in which an individual's condemnation preference is made endogenous to that individual's own past behavior doesn't readily explain why individuals, once they are induced to condemn, don't become infinitely condemnatory over time-a phenomenon that is rarely observed. Imputing a fixed "personal opinion" of the conduct to the decisionmaker and separating that from her amenabil-

Racial Change, and the Civil Rights Movement, 80 Va L Rev 7,42-43 (1994).

29 See Leon Festinger, $A$ Theory of Cognitive Dissonance (Row, Peterson 1957). 
ity to social influence, in contrast, generates a model that shows why individuals don't ordinarily follow condemnation herds to the ends of the earth, and why, consequently, there are limits to how condemnatory individuals can be induced to be.

Nevertheless, I do not mean to suggest that as a matter of fact only social influence accounts for the "hard shove/gentle nudge" dynamic. Indeed, the fact that cognitive dissonance points in the same direction as social influence and might well reinforce it in particular cases should make us more confident that the properties of individual decisionmaking that my model posits are psychologically and behaviorally realistic.

\section{REAL WORLD ILLUSTRATIONS}

My exposition so far has been abstract and theoretical. $I$ now want to make it concrete and factual through a series of real world illustrations. Some involve self-confounding hard shoves, and others remarkably productive gentle nudges.

This Part has two objectives. One is to demonstrate the empirical grounding of the "gentle nudges/hard shoves" model. The analysis will be admittedly impressionistic. Nevertheless, the cumulative effect of the illustrations should demonstrate the explanatory power of the model overall, even if individual examples remain open to counterinterpretations.

The second objective is to demonstrate the appropriate and mutually reinforcing contributions that theory and empirics make to analysis of the sticky norms phenomenon. The theoretical model in Part I invites substantial elaboration. Where exactly is the dividing line between a "gentle nudge" and a "hard shove"? What are the relative magnitudes of $P_{i}, L_{i}$, and $G_{i}$ ? Do they vary with respect to particular laws? With respect to different sorts of decisionmakers? What sorts of events determine the value of $G_{i}$, initially and over time? To suggest that the answers to these questions can be represented in conceptual terms would, I believe, overstate the precision that is realistically attainable with a theoretical model. Given the irreducibly contextual nature of social norms, the only way to progress in making the model realistic is through minute observation of the local environments that the norms inhabit.

This does not mean, however, that the model itself makes no contribution to explaining the sticky norms phenomenon. Without some general understanding of what one is looking for, the examination of particulars is aimless. The "gentle nudges/hard shoves" model, I will try to show, supplies a powerful set of concepts to guide inquiry into 
why law sometimes succeeds in changing norms and why it sometimes fails.

\section{A. Date Rape}

The career of rape law reform furnishes a dramatic example of the sticky norms problem. The impetus for reform is the convention that treats a woman's verbal protestations as consistent with a desire to have sex, a norm that promotes nonconsensual impositions by men who either genuinely mistake women's desires or strategically exploit the ambiguity surrounding expressions of nonconsent. Spurred by feminist advocacy groups, lawmakers have modified aspects of rape law that accommodate this "no sometimes means yes" norm. Thus, in some states the prosecution is relieved of the traditional requirement that it prove that the act of sexual intercourse was not only nonconsensual but also accompanied by physical force or threat of force. In others, even a "reasonable mistake" as to consent is deemed insufficient to excuse nonconsensual sex. But such reforms have proven famously ineffective. In jurisdictions that have adopted them, prosecutors are no more likely to charge men who disregard a woman's verbal protestations, and juries no more likely to convict them, than are prosecutors and juries in other states.

The failure of rape law reform fits the profile of a self-defeating "hard shove." There is genuine societal ambivalence about the "no sometimes means yes" norm. Empirical studies suggest that a substantial percentage of men and women behave consistently with the norm, either because they perceive that women who consent too readily will be deemed "promiscuous" or because they believe that their partners view a certain degree of sexual aggression as alluring." Accordingly, decisionmakers balk in the face of a legal directive to impose the degree of condemnation associated with a rape conviction on the man who fails to take "no" at face value. Jurors either nullify or more likely conclude that the woman who failed to engage in physical resistance actually did consent. Because they know that juries are reluctant to convict, moreover, prosecutors are unlikely to charge men with rape when their victims did not engage in physical resistance. And the conspicuous failure of prosecutors to charge and juries to convict reinforces the public perception that men who follow the "no sometimes

30 See generally Schulhofer, Unwanted Sex at ch 2 (cited in note 1).

31 See id at 64. 
means yes" norm aren't engaged in rape after all-at which point jurors become even less likely to convict and prosecutors to charge.

Is it possible to identify a "gentle nudge" that might shift enforcers to a more condemnatory posture? In some states, nonconsensual but nonforcible sex is styled "indecent contact" or "indecent assault."." Because this crime is punished less severely-indeed, because its very name signals that it warrants less condemnation than does rape-it is plausible to imagine that decisionmakers will be less averse to enforcing "indecent contact" laws than to enforcing rape laws against men who have internalized the "no sometimes means yes" norm. It's also possible that consistent enforcement would, over time, make members of the public revise upward their assessment of the gravity of such conduct, thereby enabling the enforcement of laws treating it as a form of "rape."

But it is also possible that "indecent assault" statutes, too, will end up reinforcing the "no sometimes means yes" norm. Critics argue that these statutes, precisely because they grade nonforcible, nonconsensual sex so much less severely than rape, are likely to corroborate the conviction that such behavior is not really worthy of criminal punishment at all.

This anxiety points up a general implementation problem for the "gentle nudges" strategy. That strategy implies that lawmakers should favor less condemnatory policies over more condemnatory ones in order to avoid triggering the "hard shove" dynamic. But policies that are only weakly condemnatory can be seen as signaling that the underlying conduct isn't genuinely worthy of condemnation, an inference that is likely to reinforce itself insofar as moral appraisals are shaped by social influence. Fines and community service penalties, for example, are thought to have this effect. ${ }^{36}$

32 See id at 258.

33 See, for example, Commonwealth v Berkowitz, 641 A2d 1161 ( $\mathrm{Pa}$ 1994). Note that Berkowitz was legislatively overruled by $18 \mathrm{~Pa}$ Cons Stat Ann $\$ 3124.1$ (Purdon 1983 \& Supp 1999), as noted in Commonwealth v Pasley, 743 A2d 521, 524 n 3 (Pa Super 1999).

34 See Schulhofer, Unwanted Sex at 104-05 (cited in note 1) (arguing that label "sexual abuse" would overcome resistance to enforcement of "rape" statutes against nonforcible, nonconsensual sex). But see David P. Bryden and Sonja Lengnick, Rape in the Criminal Justice System, 87 J Crim L \& Criminol 1194, 1198-99, 1287 (1997) (finding that legal reforms, including new terminology and reduced sentences for "sexual assault" have "generally had little or no effect on the outcome of rape cases, or the proportion of rapists who are prosecuted and convicted").

35 See, for example, Kathleen F. Cairney, Addressing Acquaintance Rape: The New Direction of the Rape Law Reform Movement, 69 St John's L Rev 291, 303 (1995) (discussing Berkowitz).

36 See Dan M. Kahan, What Do Alternative Sanctions Mean?, 63 U Chi L Rev 591, 617-30 (1996). 
What was intended as a "gentle nudge" at this point becomes a "sly wink." To avoid this pernicious transmutation, policymakers must identify strategies that strike citizens as genuinely albeit moderately condemnatory.

Katharine Baker's proposal of shaming penalties for university date rapists seems ideal in this respect. ${ }^{37}$ Shaming penalties, in the form of stigmatizing publicity and more ritualized degradation ceremonies, are enjoying a renaissance in American law for all manner of nonviolent common and white-collar crimes. ${ }^{38}$ The appeal of shame for those offenses is that shame costs less than imprisonment but is more expressive of condemnation than are fines and community service. ${ }^{39}$ Likewise, if used to enforce university sexual behavior codes, shaming punishments would unambiguously convey moral condemnation of men who engage in nonforcible but nonconsensual sex. At the same time, because shame is unambiguously less severe than imprisonment-or even than expulsion or suspension, sanctions that university administrators are frequently reluctant to impose on date rapists ${ }^{40}-$ it is unlikely to trigger the resistance of enforcers who hold ambivalent views about the "no sometimes means yes" norm. And if behavior codes enforced by shame (or by some other administrative sanction) succeed in undermining that norm on campuses, it's plausible to imagine these re-educated sensibilities graduating to society at large along with the students who hold them.

This is, of course, a matter of pragmatic conjecture. But the fit between Baker's proposal and the logic of the "hard shoves/gentle nudges" model suggests that shaming penalties are well worth trying in this setting.

\section{B. Smoking}

There is nothing conjectural about the dramatic shift in norms and regulation pertaining to smoking in the United States. Less than

\footnotetext{
37 See Katharine K. Baker, Sex, Rape, and Shame, 79 BU L Rev 663, 695-714 (1999).

38 See, for example, Dan M. Kahan and Eric A. Posner, Shaming White-Collar Criminals: A Proposal for Reform of the Federal Sentencing Guidelines, 42 J L \& Econ 365 (1999).

39 See Kahan, 63 U Chi L Rev 591 (cited in note 36).

40 See Kate Zernike, In Alleged Date Rape, Harvard Split on Call for Lesser Penalty, Boston Globe A1 (Mar 9,1999) (reporting controversy at Harvard University over faculty resistance to expulsion of male student found to have engaged in date rape); D. Morgan McVicar, 20/20 Vision?, Providence Journal-Bulletin B1 (Jan 30,1997) (reporting controversy at Brown University over case in which suspension of male student found to have engaged in nonconsensual sex with drunk female student was reduced on appeal to probation); Rosemary Harris, Handling Sexual Misconduct, Colo Springs Gazette-Telegraph B1 (Apr 28, 1996) (reporting controversy at Colorado College over decision overturning suspension).
} 
forty years ago, smoking was virtually unregulated, and bore connotations of sophistication and virility. Today, smokers and the tobacco industry confront a phalanx of regulation - from the near prohibition on public smoking to spiraling product liability judgments-and are surrounded by a mob of eager public and private enforcers who view smoking as a disgusting habit that onlookers should not be expected to tolerate.

This shift displays the pattern of incremental and escalating change associated with the "gentle nudge" dynamic. Following the release of the Surgeon General's Report in 1964, Congress moved slowly, first merely requiring warning labels and then, some six years later, banning tobacco advertisements on television. Next came a series of gradually expanding restrictions on public smoking, a trend accelerated by studies connecting "passive smoking" to health risks. Throughout this period, public attitudes-shaped by and shaping the law-became progressively more condemnatory. By the 1990s, a strong antismoking consensus had emerged, setting the stage for aggressive action by regulators, judges, and juries intent on holding the tobacco industry accountable for the burden cigarettes had imposed on the nation's health system. ${ }^{42}$

Had lawmakers attempted to dictate a regulatory regime of this intensity in one fell swoop thirty or even twenty years ago-when public attitudes toward smoking were at best ambivalent-they almost certainly would have provoked a confounding "hard shove" reaction. ${ }^{43}$ Indeed, this is exactly what has happened when regulators have attempted less incremental regulation of smoking. Thus, in the early part of the century a significant number of American states enacted tobacco prohibitions, which proved utterly ineffective." Today in Europe, public smoking bans, which regulators have attempted to impose only recently and without the gradualism characteristic of the American approach, are contemptuously defied. ${ }^{45}$

As these examples should help to make clear, public beliefs about the health consequences of smoking are not by themselves a satisfying explanation for the enforcement of anti-smoking regulations. The

41 See Joseph R. Gusfield, The Social Symbolism of Smoking and Health, in Robert L. Rabin and Stephen D. Sugarman, eds, Smoking Policy: Law, Politics, and Culture 49 (Oxford 1993).

42 See Robert A. Kagan and Jerome H. Skolnick, Banning Smoking: Compliance Without Enforcement, in Rabin and Sugarman, eds, Smoking Policy at 69 (cited in note 41).

43 See id at 78-79, 85 .

44 See Steven B. Duke and Albert C. Gross, America's Longest War: Rethinking Our Tragic Crusade Against Drugs 24 (Putnam 1993).

45 See Kagan and Skolnick, Banning Smoking at 79 (cited in note 42). 
growing public perception of the health risks associated with cigarettes did not generate demands for regulations in the 1930s and $1940 \mathrm{~s}^{46}$ - when Americans were already demonstrating a propensity to believe exaggerated and unsupported accounts of the risks of marijuana and other drugs that were being effectively suppressed. ${ }^{47}$ Europeans today know as much about the medical literature on tobacco as do Americans, who favor public smoking bans in settings (such as open-air sports arenas) in which "second hand smoke" has never been shown to pose a health risk. ${ }^{48}$ The American public views the perceived health risk of smoking as justifying regulation only because it also sees smoking as worthy of moral condemnation-although that disposition, to be sure, has been nurtured by progressively more restrictive laws predicated, in part, on health risks. ${ }^{49}$

More concretely, the career of anti-smoking regulation in the United States suggests two mechanisms of general consequence within the "hard shove/gentle nudges" model. The first is the power of a zoning or segmentation strategy for directing law and norms down the "gentle nudges" path. The regulation characteristic of the 1960s and 1970s-including the early, milder public smoking restrictions and warning labels-purported to respect the individual's decision to smoke under circumstances that didn't unduly impinge on nonsmokers. These regulations thus lacked the intolerant profile associated with outright prohibition. Nevertheless, the simple existence of these regulations affixed to the cultural landscape powerful symbolic representations of the untoward nature of the choice to smoke. They thereby helped to ground an emerging perception of smokers as deviants, as well as an emerging expectation that individuals conform to the anti-smoking norm, sensibilities that would themselves help to underwrite progressively more intolerant forms of regulation.

The second mechanism is the legal enabling of moral resentment. Before the 1970s, many individuals no doubt experienced second hand smoke as unpleasant. But because there were neither laws nor norms against smoking in public at that time, there was little these individu-

46 See Gusfield, Social Symbolism of Smoking at 56 (cited in note 41).

47 See Eva Bertram, et al, Drug War Politics: The Price of Denial 79-84 (California 1996); Jerome L. Himmelstein, The Strange Career of Marihuana: Politics and Ideology of Drug Control in America 59-71 (Greenwood 1983).

48 See Kagan and Skolnick, Banning Smoking at 84 (cited in note 42); Lawrence Lessig, The Regulation of Social Meaning, 62 U Chi L Rev 943, 1030 (1995).

49 Consider Gusfield, Social Symbolism of Smoking (cited in note 41); Lessig, 62 U Chi L Rev at $1028-30$ (cited in note 48 ).

50 See Gusfield, Social Symbolism of Smoking at 65 (cited in note 41) (noting that public bans mark the smoker as "pariah" and force him symbolically to act out the role of outcast). 
als could do other than silently forbear their irritation. Once even mild antismoking regulations were in place, however, it became clear that nonsmokers were entitled to be free of smoke and that smokers were the parties obliged to forbear. Consequently, irritated nonsmokers were much more likely to express their disapproval. Indeed, at that point, even individuals who might not otherwise have found exposure to smoke unpleasant were more likely to object to public smoking, which against the background of public smoking bans began to express contemptuous disregard for the interests of nonsmokers. Enabled by antismoking regulation, this sense of indignation accounts for the zealous informal enforcement of antismoking regulations. ${ }^{\text {s1 }}$

The zoning strategy and resentment effect formed the contact points for a charged exchange of energy between laws and norms. As mild as they were, the initial antismoking regulations in the 1960 s and 1970 s created an expectation of conformity, the disappointment of which predictably contributed to the demand both for progressively tougher laws and for the effective enforcement of them.

\section{Domestic Violence}

Much like date rape, domestic violence law is a field in which reform efforts have been subverted from within. When states enact mandatory arrest policies, police departments refuse to implement them. When states raise the penalties for repeat offenders, prosecutors drop cases, juries acquit, and judges refuse to sentence severely. When judges make nonabuse a condition of probation, probation officers look the other way. ${ }^{52}$

This is another example, then, of the futility of applying hard shoves to sticky norms. Though not as prevalent as it once was, the view that occasional violence is a normal part of family life persists. ${ }^{53}$ Many decisionmakers either hold this view or empathize with individuals who do. Predictably, these decisionmakers refuse aggressively to enforce condemnatory domestic violence laws. Indeed, such laws

51 Consider Kagan and Skolnick, Banning Smoking (cited in note 42).

52 See, for example, Zorza, $83 \mathrm{~J}$ Crim L \& Criminol at 65 (cited in note 2); Daniel J. Bell, Family Violence in Small Cities: An Exploratory Study, 12 Police Stud 25 (1989).

53 Consider Murray A. Straus, Physical Violence in American Families: Incidence, Rates, Causes, and Trends, in Dean D. Knudsen and JoAnn L. Miller, eds, Abused and Battered: Social and Legal Responses to Family Violence 17, 27 (Aldine 1991) ("The informal social norms have changed much less than the law has. Almost a third of American men and a quarter of American women perceive that it is normal for a husband or wife to slap the other 'on occasion."').

54 See, for example, Neil Websdale, Rural Woman Battering and the Justice System: An Ethnography ch 4 (Sage 1998) (analyzing several factors that compromise the policing of rural woman battering, such as patriarchal attitudes, the "ol' boys network," patronage politics, and 
are perceived as triggering "backlashes" among police officers and other officials who see domestic violence reforms as ideologically inspired interference with their discretion."

The failed campaigns to reform domestic violence law and rape law illustrate a political dynamic especially likely to generate ineffective "hard shoves." Well organized and intensely interested advocacy groups can often secure legislation that is out of line with the preferences of the median voter. ${ }^{s 6}$ That is what happened in the fields of domestic violence law and rape law, where legislative reforms reflected strong, feminist-inspired critiques of norms that had not yet been fully repudiated by society at large. Because the feminist advocacy groups did not enjoy the same influence over enforcers as they did over legislators, the reform efforts predictably generated resistance at the enforcement stage.

We might therefore expect the sponsors of such legislation to attempt to concentrate enforcement authority in decisionmakers specially selected for their commitment to attacking hierarchical gender norms. The Violence Against Women Act, for example, grants substantial funds to states to "develop[], train[], or expand[ ] units of law enforcement officers and prosecutors specifically targeting violent crimes against women, including the crimes of sexual assault and domestic violence." ${ }^{\text {"I }}$ Decisionmakers attracted to such units are less likely to balk at enforcing severely condemnatory laws. In addition, when such individuals are grouped exclusively with one another, their collective propensity to enforce should feed on itself through the mechanisms of social influence. Indeed, one risk of such a strategy is that the conspicuous zeal of specialized enforcers will itself publicly discredit them and the laws they enforce, as is alleged to have oc-

low tax base); Eve S. Buzawa, Thomas L. Austin, and Carl G. Buzawa, The Role of Arrest in Domestic Versus Stranger Assault: Is There a Difference?, in Eve S. Buzawa and Carl G. Buzawa, eds, Do Arrests and Restraining Orders Work? 150 (Sage 1996) (finding that officers make fewer arrests for domestic assault cases than for stranger assault cases); Michael G. Breci, Police Officers' Values on Intervention in Family Fights, 10 Police Stud 192 (1987) (finding that black officers and those with higher levels of education and fewer years served were less likely to favor mandatory arrest policies, while white officers and those with less education and more experience were more likely to do so).

55 See Daniel G. Saunders, The Tendency to Arrest Victims of Domestic Violence: A Preliminary Analysis of Officer Characteristics, $10 \mathrm{~J}$ Interpersonal Violence 147, 148 (1995) (citing two recent studies).

56 See Mancur Olson, The Logic of Collective Action: Public Goods and the Theory of Groups (Harvard 1965).

57 Violence Against Women Act $\S$ 40121(a)(3), Pub L No 103-322, 108 Stat 1911 (1994), codified at 42 USC $\$ 3796 \mathrm{gg}(\mathrm{b})(2)$ (1994). 
curred with the Bureau of Alcohol, Tobacco, and Firearms, for example.

Accordingly, rather than attempt to bypass ordinary decisionmakers, reformers might do even better with a "gentle nudges" strategy, which over time would induce those decisionmakers and members of the public at large to become less tolerant of domestic violence. What might "gentle nudges" look like in the domestic violence context? One possibility would be a variant of the shaming penalties that

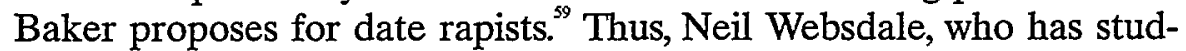
ied the ineffectiveness of domestic violence reform in Kentucky, advocates "enlist[ing] the support of rural men who eschew battering" to participate in publicity campaigns that reinforce the connotation of "violence against women [as] cowardly or unmanly." Such a regime of informal shaming, which trades on the same social bonds that make rural police reluctant to enforce more punitive domestic violence laws, "might be the thin-end-of-the-wedge toward a longer-term challenge to some of the nonviolent patriarchal control mechanisms in families and elsewhere." $"$ (11

Another possibility-advocated by David Zlotnick-would be renewed attention to civil and criminal contempt remedies for protective orders. ${ }^{62}$ This approach would aim to trigger a variation of the resentment effect responsible for the change in norms and laws pertaining to smoking. Just as nonsmokers who don't find smoke irritating are nevertheless likely to react indignantly to smokers who openly defy public smoking bans, so judges who aren't otherwise overly concerned with domestic violence are likely to react with indignation toward abusers who openly flout judicial authority by violating courtissued protective orders. Having become accustomed to condemning domestic abusers in this setting, and seeing that their orders are not producing the desired conformity, judges might become more willing to condemn domestic violence per se over time.

Granted, neither the informal shaming advocated by Websdale nor the renewed attention to contempt proposed by Zlotnick carries the expressive wallop of the severe criminal penalties favored by some domestic violence activists. But if the goal of reform is ultimately to

\footnotetext{
58 See, for example, Rowland Nethaway, It's Time to Disband an ATF Mired in Cowboy Culture, Post and Courier (Charleston, SC) A11 (Oct 26, 1995); George Lardner, Jr., Citing Ruby Ridge, Specter Calls for Abolition of ATF, Wash Post A4 (Oct 25,1995).

59 See note 37 and accompanying text.

60 Websdale, Rural Woman Battering at 208 (cited in note 54).

61 Id at 208-09.

62 See David Zlotnick, Empowering the Battered Woman: The Use of Criminal Contempt Sanctions to Enforce Civil Protection Orders, 56 Ohio St L J 1153,1179-1215 (1995).
} 
change behavior and norms, rather than to score short-term expressive victories, activists should resist the temptation to translate their influence over legislators into laws that enforcers can't realistically be expected to carry out.

\section{Drugs}

The story of narcotics regulation in the United States represents the most dramatic example of the power of "gentle nudges" to shift norms and laws from a condition of ambivalence to one of extreme intolerance. With little if any conscious planning or direction, the enactment of mild tax provisions matured in time into a seemingly permanent cycle of escalating waves of public condemnation and punitive responses.

Drug regulation was late in coming and began fitfully. At the turn of the century, the sale and consumption of opium, cocaine, and marijuana were all perfectly legal and commonplace. Opposed by a variety of mainstream interests, early attempts to enact a national prohibition were rebuffed in Congress in 1909 and 1910. The first significant federal drug law, the Harrison Narcotics Act of $1914,{ }^{63}$ did nothing more than impose tax and licensing regulations designed to confine the power to dispense drugs to politically powerful vendors within the medical industry. Early regulation of marijuana was similarly unambitious.

Once in place, however, these provisions helped to alter public perceptions of the character of drugs and drug users. The simple existence of these laws underscored the untoward nature of the controlled substances. Zealous moral crusaders and bureaucratically selfaggrandizing enforcers fueled this perception, depicting addicts as frenzied criminals and the physicians who serviced them as unscrupulous "dope doctors." Bombarded with these images, a previously indifferent public had by the 1930s come to see narcotics as dangerous substances with no licit value. ${ }^{6 .}$

This change in attitudes initiated a mutually reinforcing interaction between punitive legal responses and condemnatory norms. The

63 Pub L No 63-223, 38 Stat 785 (1914), superseded by the Internal Revenue Code of 1939.

64 See Bertram, et al, Drug War Politics at 61-69 (cited in note 47); John C. McWilliams, Through the Past Darkly: The Politics and Policies of America's Drug War, in William O. Walker III, ed, Drug Control Policy: Essays in Historical and Comparative Perspective 5, 10 (Penn State 1992).

65 See McWilliams, Through the Past Darkly at 17 (cited in note 64); Himmelstein, Strange Career of Marihuana at 49-59 (cited in note 47).

66 See Bertram, et al, Drug War Politics at 69-77 (cited in note 47); Himmelstein, Strange Career of Marihuana at 59-63 (cited in note 47). 
states were the first to impose criminal prohibitions, followed by the federal government in the early $1950 \mathrm{~s} .{ }^{67}$ Confronted with evidence that these laws were not staunching the drug trade-and incited by politicians intent on exploiting growing fears of drugs-the public soon demanded even tougher laws, which Congress quickly enacted. Against the background of these laws, public attitudes hardened all the more, prompting additional punitive responses. With only brief interruptions, this spiral has continued to the present day. ${ }^{68}$

The only significant reversal in this trend involved marijuana. In the late 1960s and early 1970s, many states either downgraded the criminal classification of marijuana possession or decriminalized this offense altogether. ${ }^{69}$ This development, too, fits the "hard shove/gentle nudges" model. Because individuals' condemnation preferences are not infinitely adaptable, the steady expansion of criminal punishment at some point risks triggering a backlash. ${ }^{70}$ This is exactly what happened with marijuana possession: at the point at which the law began to be applied to white middle-class college students, members of the social mainstream began to object, triggering a self-reinforcing wave of opposition."

The "hard shove/gentle nudge" model can also help to explain why drug prohibition in the main experienced a fate so different from alcohol prohibition. The story of the temperance movement is too complex to be reduced to a single social mechanism. ${ }^{2}$ But at least one of the reasons that Prohibition failed was the reluctance of local law enforcers to carry out severe restrictions, a trend that reinforced the popular sentiment that Prohibition was illegitimate. ${ }^{73}$ Indeed, the backlash against Prohibition did not escape the notice of officials within the young Federal Bureau of Narcotics (FBN). During the 1930s, top officials within the FBN urged cautious expansion of drug laws to avoid the "risk[ ] [of] fomenting public discontent and undermining their own legitimacy."

67 See Bertram, et al, Drug War Politics at 77,84 (cited in note 47).

68 See id at 100-01.

69 See Himmelstein, Strange Career of Marihuana at 103-04 (cited in note 47).

70 See Part I.B.

71 See Himmelstein, Strange Career of Marihuana at 99-105 (cited in note 47).

72 For a general discussion, see Joseph R. Gusfield, Symbolic Crusade: Status Politics and the American Temperance Movement (Illinois $2 \mathrm{~d}$ ed 1986) (describing social meanings that motivated temperance controversy).

73 See Charles Merz, The Dry Decade 71-73 (Doubleday, Doran 1969); Andrew Sinclair, Prohibition: The Era Of Excess 190-214, 220-41 (Little, Brown 1962); United States National Commission on Law Observance and Enforcement, Enforcement of the Prohibition Laws of the United States 59 (Wickersham Commission 1931).

74 Himmelstein, Strange Career of Marihuana at 56 (cited in note 47). See also id at 139. 
But it's unlikely that even these officials consciously anticipated the long-term payoffs of the incrementalist strategy. Transformative "gentle nudges" can come as just as big a surprise to lawmakers as can self-defeating "hard shoves." The'sponsors of the Harrison Act and other early regulatory schemes did not intend those measures to ban drugs. Indeed, drug use moderates applauded these laws, which they saw as sensible public health alternatives to criminal prohibition. ${ }^{75}$ The enforcement of even these relatively mild laws, however, set in motion forces that caused members of the public to revise upward their assessment of the dangerousness of drugs, a shift that predictably folded back on itself and led to increasingly tougher laws. The story of drug regulation in America is a testament to the fragility of moderation in a moral and regulatory environment constructed by social influence.

\section{E. Drunk Driving}

Historically, drunk driving is another crime the deterrence of which has been severely constrained by sticky norms. Legislatures regularly erupt with tough legislation in the form of stricter penalties for first-time and repeat offenders and less tolerant blood-alcohol levels. But whenever they do, police officers, prosecutors, judges, and juries routinely compensate by easing up in their respective contributions to enforcement." "Whatever its status in the legislative corridors and councils, in the appellate courts, or in the newspapers, in day-today enforcement and adjudication, DUIA is treated as if, like other traffic offenses, it is the normal behavior of motorists." Unsurprisingly, empirical studies of the deterrent value of punitive measures have typically found no effect. ${ }^{78}$

Nevertheless, recent evidence suggests that drunk driving is on the decline. Since the mid-1980s, drunk driving fatalities have dropped considerably, as has the (self-reported) incidence of driving under the influence. Social science studies link this change less to an increased awareness or fear of criminal penalties than to a heightened sense that drunk driving is socially unacceptable. Shame has repaired the deterrence breach.

\footnotetext{
75 See id at 67-68; McWilliams, Through the Past Darkly at 11 (cited in note 64).

76 See, for example, Ross, Confronting Drunk Driving at 56-58 (cited in note 2); Lewis R. Katz and Robert D. Sweeney, Jr., Ohio's New Drunk Driving Law: A Halfhearted Experiment in Deterrence, 34 Case W Res L Rev 239, 288-95 (1983-84).

77 Joseph R. Gusfield, The Culture of Public Problems: Drinking-Driving and the Symbolic Order 140 (Chicago 1981).

78 See Ross, Confronting Drunk Driving at 58-62 (cited in note 2).

79 See Dale E. Berger and William D. Marelich, Legal and Social Control of AlcoholImpaired Driving in California: 1983-1994, 58 J Stud Alcohol 518 (1997); Harold G. Grasmick,
} 
The drunk driving story, too, conforms to the "gentle nudges/hard shoves" model. The traditional punitive strategy failed in the manner characteristic of a self-defeating "hard shove": because they dramatically confounded widespread norms, severely condemnatory laws predictably triggered resistance on the part of enforcers. However, in the 1980s newly formed advocacy groups-most prominently Mothers Against Drunk Driving-began a well organized moral campaign against drunk driving. This campaign was significant less for its effect on law - the content of which had been becoming progressively more severe for decades - than for its effect on public attitudes, which became suddenly more condemnatory in the late 1980s. Informal enforcement of law, in the form of privately imposed stigma, was the gentle nudge that shook loose the sticky norms that condoned drunk driving.

Or at least this is one hypothesis. It is difficult to disentangle the respective contributions that increasingly condemnatory norms and severe penalties have made to the reduction of drunk driving in the last ten to fifteen years. But one way to test their relative effects might be to examine whether the level of enforcement of drunk driving laws has changed over time. If the "gentle nudges" hypothesis is correct, the change in norms relating to drunk driving should now be making decisionmakers more willing to enforce tough drunk driving laws. Whereas the traditional deterrence model suggests that stricter enforcement causes changes in behavior, the "gentle nudges" model suggests that changes in behavior that reflect changes in norms cause stricter enforcement.

\section{F. Sexual Harassment}

Sexual harassment law is a site of intense legal, political, and cultural conflict. Feminist reformers have achieved an immense transformation of the legal rules relating to sexual behavior in the workplace. But "[w]ith each stride forward, backlash"-from judges, political activists, and members of the regulated public_-"has also set in." The "sticky norm" model can help to illuminate these thrusts and parries, which reflect the extent to which sexual harassment law has alter-

Robert J. Bursik, Jr., and Bruce J. Arneklev, Reduction in Drunk Driving as a Response to Increased Threats of Shame, Embarrassment, and Legal Sanctions, 31 Criminol 41 (1993).

80 See Berger and Marelich, $58 \mathrm{~J}$ Stud Alcohol at 521-23 (cited in note 79); Grasmick, Bursik, and Arneklev, 31 Criminol at 61-62 (cited in note 79).

81 National Council for Research on Women, Sexual Harassment: Research \& Resources 2 (3d ed 1995). 
nated at various points and along various dimensions between "gentle nudges" and "hard shoves."

Attitudes toward sexual harassment have changed dramatically over the last twenty years. Indeed, few Americans had any attitude about it whatsoever before Catharine MacKinnon wrote The Sexual Harassment of Working Women in 1979. As resented as they might have been by female workers, ogling, lewd comments and jokes, persistent requests for dates, and the like were perfectly ordinary events. Even men who conditioned their female subordinates' job prospects on engaging in sex did not risk censure. Today most Americans-male and female-view such behavior as unacceptable.

To be sure, sexual harassment law is in part a consequence of this shift in attitudes, but it is also in part the cause of it. By making such conduct unlawful, sexual harassment doctrine has promoted the transformation of social norms in two distinct ways. First, it has created the self-fulfilling appearance of a growing consensus. Sizeable jury verdicts-such as the $\$ 7.1$ million award in the notorious Baker \& McKenzie case ${ }^{84}$-convey not only that the law prohibits sexual badgering and groping, but that ordinary citizens view such behavior as morally outrageous. Furor over events such as the Tailhook scandal and the Clarence Thomas-Anita Hill controversy amplifies the impression that such conduct is widely condemned. Through the mechanism of social influence, individuals predictably adapt their own values to what they perceive others believe, thereby adding momentum to the antiharassment bandwagon.

Second, sexual harassment law has infused a norm-reinforcing sensibility of resentment into workplace culture. Vicarious liability doctrines create significant incentives for businesses to police the behavior of employees. ${ }^{86}$ In general, managers are much more likely to

82 Catharine A. MacKinnon, Sexual Harassment of Working Women: A Case of Sex Discrimination (Yale 1979).

83 See Laura Reese and Karen Lindenberg, Implementing Sexual Harassment Policy: Challenges for the Public Sector Workplace 43-46 (Sage 1999) (finding consensus that such behavior counts as harassment); United States Merit Systems Protection Board, Sexual Harassment in the Federal Workplace: Trends, Progress, Continuing Challenges 5-11 (GPO 1995) (documenting changing attitudes toward what forms of behavior count as harassment); Douglas D. Baker, et al, Perceptions of Sexual Harassment: A Reexamination of Gender Differences, in Edmund Wall, ed, Sexual Harassment: Confrontations and Decisions 217, 220-21 (Prometheus 1992) (finding high degree of agreement in classification across genders).

84 Weeks v Baker \& McKenzie, 1994 WL 636488 (Cal Super 1994), modified, 1994 WL 774633 (Cal Super 1994), affd 63 Cal App 4th 1128 (1998).

85 See National Council for Research on Women, Sexual Harassment at 1 (cited in note 81) (identifying these and like cases and events as contributing to shifting attitudes).

86 See Faragher $v$ City of Boca Raton, 524 US 775, 798-810 (1998) (recognizing affirmative defense to vicarious liability where firm takes affirmative steps to prevent harassment); Bur- 
become committed to the norms embodied in regulatory law when businesses are pressed into enforcing those norms themselves. ${ }^{87}$ Under those conditions, violations express disrespect not only for the values embodied in the law, but also for the authority of the managers charged with administering firm policies. Indeed, managers have reason to be especially chagrined by employees who persist in treating coworkers as sexual fair game, since the typical sexual harassment suit costs a firm $\$ 15$ million in litigation costs. ${ }^{\$}$ Thus, like nonsmokers who don't find smoke physically annoying but who feel slighted when smokers flagrantly defy public smoking bans, or judges who aren't personally roused by domestic violence but who do take umbrage at batterers who violate judges' protective orders, even managers who aren't ideologically committed to sexual harassment laws can be expected to resent harassers who disregard firm policies. And because employees are likely to pay more attention to and invest greater authority in the views of managers and coworkers than the views of remote legislators and judges, the resentment of the managers is likely to be an even stronger cue than is the law generally that the tide of opinion has turned against harassment.

The transformative effect of law on sexual harassment norms again suggests the potency of gentle nudges. The current state of American sexual harassment law is the product of the modest but steady accretion of administrative, judicial, and legislative directives. The Equal Employment Opportunity Commission first recognized the "hostile work environment" theory of sex discrimination in 1980, an interpretation of Title VII that the Supreme Court ratified six years later. $^{\text {*0 }}$ Between 1987 and 1991, numerous circuit courts recognized the "reasonable woman" standard, a development designed to underscore for juries and judges the inappropriateness of evaluating harassers' conduct against the traditional norms characteristic of maledominated workplaces." Congress joined in 1991, significantly

\footnotetext{
lington Industries, Inc v Ellerth, 524 US 742,754-66 (1998) (same).

87 For a general discussion, see Ian Ayres and John Braithwaite, Responsive Regulation: Transcending the Deregulation Debate (Oxford 1992).

88 See Reese and Lindenberg, Implementing Sexual Harassment Policy at 3-4 (cited in note 83) (noting that defendant companies are also often burdened by productivity losses, poor morale, administrative costs, and adverse publicity as the result of a harassment trial).

89 See 45 Fed Reg 74677 (Nov 10, 1980); 29 CFR \& 1604.11a (2000) ("Unwelcome sexual advances, requests for sexual favors, and other verbal or physical conduct of a sexual nature constitute sexual harassment when ... such conduct has the purpose or effect of ... creating an intimidating, hostile, or offensive working environment.").

90 Meritor Savings Bank v Vinson, 477 US 57,64-69 (1986).

91 See Ellison v Brady, 924 F2d 872, 879-80 (9th Cir 1991); Andrews $v$ City of Philadelphia, 895 F2d 1469, 1482 (3d Cir 1990); Yates v Avco Corp, 819 F2d 630, 637 (6th Cir 1987).
} 
strengthening sexual harassment law by authorizing compensatory and punitive damages. ${ }^{\text {s2 }}$ And finally the Supreme Court in 1998 authoritatively approved broad vicarious liability doctrines that put pressure on employers to adopt their own antiharassment policies. ${ }^{93}$

It seems highly doubtful that the EEOC, Congress, or the courts could have effectively mandated enforcement of the contemporary antiharassment regime in 1976, when the image of the lecherous boss chasing his secretary around the desk still provoked laughter. The European experience confirms this hypothesis. Seeking to bypass the gradualism that characterized the evolution of American law, the European Union in 1991 proposed wholesale adoption of the American regime. But precisely because their norms had not been subject to the transformative effect of incremental reform, the EU member states rejected this directive, which they derided as a product of American Puritanism. France has made sexual harassment a criminal offense, but its exceptional status is only apparent: precisely because this remedy is so out of keeping with national mores, France's law goes unenforced against conduct that would clearly be actionable under American law.'

Indeed, the use of civil rather than criminal enforcement might help to explain why American sexual harassment law has proven relatively more effective than have rape law and domestic violence law reforms. All three seek to dislodge traditional gender norms. But because rape law and domestic violence reforms do so with highly afflictive, and hence highly condemnatory, criminal sanctions, they predictably generate greater resistance among decisionmakers than do milder civil damages remedies. In addition, two of the decisionmakers primarily responsible for such resistance-prosecutors and policeplay no role in sexual harassment suits, which are initiated and prosecuted by aggrieved plaintiffs eager for redress of their injuries. Finally, federal sexual harassment actions, which were tried to judges until the advent of the compensatory and punitive damages remedies in 1991, also bypassed juries, which likewise have played a key blocking role in date rape reforms.

92 Civil Rights Act of $1991 \S 102$, Pub L No 102-166, 105 Stat 1071 (1991), codified at 42 USC § 1981a (1994).

93 See Faragher, 524 US at 807; Burlington Industries, 524 US at 765.

94 See Abigail Cope Saguy, Defining Sexual Harassment in France and the United States, 1975-1998 7-9, 12, 110-11 (unpublished manuscript, Jan 2000); Tanya Martinez Shively, Sexual Harassment in the European Union: King Rex Meets Potiphar's Wife, 55 La L Rev 1087, 1144-46 (1995); Anita Bernstein, Law, Culture, and Harassment, 142 U Pa L Rev 1227,1257-87 (1994).

95 See Saguy, Defining Sexual Harassment at 62, 102-03 (cited in note 94). 
It would be a mistake, however, to depict the American sexual harassment regime as having escaped entirely from the constraints of traditional norms. Indeed, precisely because sexual harassment law has played so conspicuous a role in attacking those norms, its development has at times provoked the type of resistance characteristic of hard shoves. "It is not a coincidence that the United States has both the most advanced sexual harassment doctrine in the world and also the world's most varied, numerous, famous, and successful victimblamers." $\%$

Such resistance sometimes comes from the judiciary. Lower court judges have constructed a variety of limiting principles that blunt expansive legislation and Supreme Court precedents. Patterned on doctrines that conform rape law to the norm that "no sometimes means yes," these principles defeat liability unless the plaintiff actively resisted the defendant's sexualization of the work environment. ${ }^{n}$ The existence of these principles is the predictable result of laws that call upon judges to repudiate norms that they themselves have internalized. ${ }^{\text {s. }}$

Politics furnishes another source of resistance. Socially conservative activists foment public sentiment (or at least the appearance of the sentiment) that sexual harassment law "has gone too far" by adroitly publicizing seemingly extreme cases." This sentiment spawns legislative initiatives to curtail sexual harassment remedies, which can reinforce the perception that expansive policies are out of sync with public opinion. ${ }^{100}$

Finally and most importantly, sexual harassment law has provoked resistance in the workplace. The policies that firms adopt to assure compliance with the law often impose standards that employees

\footnotetext{
96 Bernstein, 142 U Pa L Rev at 1278 (cited in note 94).

97 See Susan Estrich, Sex at Work, 43 Stan L Rev 813 (1991).

98 As one court infamously put it,
}

[I]t cannot seriously be disputed that in some work environments, humor and language are rough hewn and vulgar. Sexual jokes, sexual conversations and girlie magazines may abound. Title VII was not meant to-or can-change this. It must never be forgotten that Title VII is the federal court mainstay in the struggle for equal employment opportunity for the female workers of America. But it is quite different to claim that Title VII was designed to bring about a magical transformation in the social mores of American workers.

Rabidue v Osceola Refining Co, 805 F2d 611, 620-21 (6th Cir 1986).

99 See Davis v Monroe County Board of Education, 526 US 629 (1999) (holding that fifthgrade student had stated a claim of student-on-student harassment under Title IX); George Will, Six-Year-Old Harassers, Newsweek 88 (June 7,1999); Mona Charen, Affectionate Professor: Sexual Predator or Feminist Victim?, St Louis Post-Dispatch B7 (Aug 31,1995). 81).

100 See National Council for Research on Women, Sexual Harassment at 2 (cited in note 
find unrealistic-for example, flat prohibitions on dating other employees-or remedies that they view as too severe-for example, dismissal or demotion of the harasser. ${ }^{101}$ Accordingly, there is reluctance to invoke internal disciplinary procedures. This reluctance extends not just to the managers who are charged with enforcing these regulations, but also to the women who are supposed to be protected by them: studies suggest that the vast majority of the women who decline to report harassment hold back because they don't want to trigger formal sanctions against the harasser. ${ }^{102}$

The reluctance to invoke antiharassment policies, moreover, is self-reinforcing. When they observe that formally prohibited behavior goes unpunished, employees who harbor ambivalent feelings about harassment are likely to conclude that existing regulations are in fact too severe. ${ }^{103}$ Those who unequivocally resent such behavior, on the other hand, are likely to infer that such behavior is condoned by their superiors. ${ }^{106}$ Both types of impressions conduce to more harassment. ${ }^{105}$ This is the signature feedback effect of self-defeating hard shoves.

In sum, the evolution of norms and law relating to sexual harassment has been influenced by dynamics characteristic of both gentle nudges and hard shoves. Whereas most of the other bodies of law I have discussed have either steadily conflicted with or steadily transformed social norms, the impact of sexual harassment law has been marked by alternating short-term shifts and counter-reactions with an overall trend toward slow reform.

Is there a strategy for smoothing out and accelerating the transformation of workplace norms? Counterintuitively, Anita Bernstein has proposed that the United States take a step in the direction of Europe. ${ }^{106}$ Rejecting the American emphasis on litigation, European nations have instead encouraged firms to combat sexual harassment with informal mediation programs. Although they assume a variety of

101 See id at $39-40$.

102 See Patricia A. Frazier, Overview of Sexual Harassment From the Behavioral Science Perspective, paper presented at American Bar Association, National Institute on Sexual Harassment (Oct 15-18, 1997), available on Westlaw at N97SHCB ABA-LGLED B-1, *B-5. See also United States Merit Systems Protection Board, Sexual Harassment in the Federal Workplace at 34-35, 37-38 (cited in note 83).

103 Consider Reese and Lindenberg, Implementing Sexual Harassment Policy at 57 (cited in note 83); National Council for Research on Women, Sexual Harassment at 40 (cited in note 81).

104 Consider Reese and Lindenberg, Implementing Sexual Harassment Policy at 57 (cited in note 83).

105 See Frazier, Overview of Sexual Harassment at *2-3 (cited in note 102) (describing social science data showing that harassment is more likely in organizations in which harassment is perceived to be tolerated).

106 See Bernstein, 142 U Pa L Rev at 1287-94 (cited in note 94). 
forms, these schemes typically require the offending employee to meet with the aggrieved employee and a third party whom the aggrieved employee has selected, and to propose a course of future conduct that the aggrieved employee finds acceptable. The aim is not to compensate the aggrieved employee or to punish the offending one, but only to assure future workplace conditions acceptable to the aggrieved employee. Indeed, the proceedings are structured to avoid any formal determination of misconduct. Bernstein proposes incentives for U.S. firms to adopt similar programs and for U.S. employees to mediate rather than sue. ${ }^{10}$

The gentle nudges/hard shoves theory helps explain why Bernstein's theory makes sense. By shifting emphasis away from courts, informal mediation would minimize the opportunities for conservative judges to slow the evolution of American sexual harassment norms. It would also reduce the stockpile of unusual or anomalous cases that conservative activists exploit to tar sexual harassment law with the image of cultural extremism. At the same time, informal mediation would enhance the norm-shaping power of internally administered sexual harassment policies. Because informal mediation does not result in a formal determination of fault or any punitive sanction against the offending employees, aggrieved employees should be much more willing to invoke mediation than they are to invoke existing disciplinary policies. When other employees see how readily commonplace forms of harassment trigger the mediation procedure, moreover, they are likely to be disabused of the notion that such conduct is in fact condoned; in that climate, victims are even more likely to report harassers, and potential harassers even less likely to harass. Thus, however effective or ineffective informal mediation might be in changing norms in Europe, informal mediation might well supply the constructive "gentler" nudge that perfects the transformation of sexual harassment norms in the American workplace.

\section{NORMATIVE AND PRESCRIPTIVE IMPLICATIONS}

Having theoretically modeled and empirically illustrated the "hard shoves/gentle nudges" dynamic, I now want to address its policy significance. What does this theory imply about the proper legal strategies for dealing with sticky norms?

The truth is that the "hard shoves/gentle nudges" theory generates no normative implications. Behavioral phenomena don't have politics. They can propel lawmakers just as readily toward benighted

107 See id. 
policies as toward enlightened ones. The "hard shoves/gentle nudges" theory tells us only that certain legal strategies are likely to reinforce existing norms, and others to dislodge them. But to know which of these effects to prefer, we must consult some independent source of moral insight. Thus, the "hard shoves/gentle nudges" theory can yield results no better, normatively speaking, than the moral judgments of those who seek to apply it.

Assuming we do know what state of affairs is best, however, the "hard shoves/gentle nudges" theory does generate important prescriptive implications. I will describe five of them.

1. Don't be greedy. Norm reformers must resist the temptation to overreach. Because they are likely to hold their views intensely and to enjoy certain organizational advantages related to their relatively small size, critics of existing norms will often exercise disproportionate influence over legislators. If, however, they use their influence to secure laws that condemn existing norms substantially more severely than do most law enforcers, they are likely to provoke the confounding effect characteristic of "hard shoves." This is the story behind the failed attempts to use the law to change norms relating to date rape and domestic violence, and drunk driving before the mid-1980s.

Instead, norm reformers should use their political influence to attack objectionable norms incrementally. This strategy would exploit the "gentle nudges" dynamic responsible for the dramatic change in the norms and laws relating to smoking and drugs, and drunk driving after the mid-1980s.

2. Pay attention to social meaning. How to implement the gentle nudges strategy will be excruciatingly context dependent. The key is to identify legal strategies that are sufficiently severe to avoid being construed as tacit endorsements-the "sly wink" effect-but sufficiently mild to avoid coming across as morally fanatical. Shaming punishments will sometimes be attractive for this purpose, since in comparison to afflictive sanctions such as imprisonment shaming is unambiguously mild, while in comparison to less expressive sanctions such as fines and community service shaming is unambiguously condemnatory. Zoning or segmentation strategies-such as those used incrementally to tighten regulation of smoking-have analogous properties: they leave no doubt that the conduct in question is being condemned, yet avoid the connotation of extremism associated with universal prohibition.

3. Harness moral resentment. When possible, norm reformers should give prospective enforcers a reason to see compliance with the law as a reflection of their authority or status. In that situation, even 
decisionmakers who are ambivalent about the values that animate the law will nevertheless feel invested in effective enforcement. And their willingness to enforce, even when induced by these means, will thereafter help to construct a climate in which other decisionmakers and members of the public at large become more condemnatory of the regulated behavior. This "moral resentment" dynamic appears to be part of the explanation for the success of anti-smoking regulations, the violation of which is understood to convey disrespect toward nonsmokers, and sexual harassment laws, the violation of which defies the authority of workplace managers. It is conceivable, too, that judges might be induced to be more aggressive in enforcing domestic violence laws if pushed to issue more protective orders, the violation of which puts judges' authority into doubt.

4. Prefer civil to criminal. The "hard shoves/gentle nudges" theory suggests that civil law will often be more effective in changing norms than will criminal law. This conclusion might seem counterintuitive precisely because the criminal law, in distinction to civil law, is usually understood to reflect society's shared moral ideals, a feature of it that makes criminal law seem a promising vehicle for reforming citizens' attitudes. ${ }^{108}$ But precisely because criminal punishments are understood to reflect strong moral condemnation, decisionmakers are likely to balk at enforcing them when they feel some measure of personal commitment to the norms that the law is trying to change. They are likely to experience less aversion to enforcing civil remedies, which tend to be milder both in their regulatory incidence and in their social meaning; yet as they become accustomed to enforcing civil sanctions, decisionmakers are likely to become progressively more condemnatory of the underlying conduct and thus more supportive of punitive measures at a later time.

In addition, the effective enforcement of criminal law depends on the cooperation of a larger number of institutional actors than does effective enforcement of civil remedies. At least where civil remedies are implemented through private causes of action, they bypass police and prosecutors, and minimize the role of juries, all of whom can initiate self-reinforcing waves of resistance to laws that attack deep-seated norms.

These advantages of civil over criminal law in norm reform help to explain why sexual harassment law has had a bigger impact in

108 See, for example, Kenneth G. Dau-Schmidt, An Economic Analysis of the Criminal Law as a Preference-Shaping Policy, 1990 Duke L J 1, 2 (arguing that "criminal punishment is intended to promote various social norms of individual behavior by shaping the preferences of criminals and the population at large"). 
changing traditional gender norms than has either rape law reform or domestic violence law reform. Norm reformers should therefore be more attentive to the possibility of using civil law than they traditionally have been.

5. Be wary of compromise? There is intense dissensus in our society on whether many forms of seemingly private or consensual behavior-from drug use to gambling to various forms of sex-are proper objects of legal regulation. One traditionally appealing solution has been to split the moral difference, making the underlying conduct illegal but keeping the effective penalty small. Legal historian Lawrence Friedman describes this state of affairs, which obtained with respect to all manner of vice crime at the turn of the century, as the Victorian Compromise.

But the Victorian Compromise has broken down, particularly for drug offenses. The "hard shoves/gentle nudges" theory helps to explain why. Even mild punishments can ground expectations of conformity. When those expectations are unmet, members of the public are likely to demand more severe punishments, the enactment of which are likely to spur even more condemnatory public attitudes, which are likely to lead to even tougher punishments, and so forth and so on. This is the story behind America's spiral toward ever more draconian drug laws.

Those who oppose morally intrusive norms, then, should be loath to accept even relatively mild legal enforcement of them, lest a "gentle nudge" initiate an avalanche of illiberality. By the same token, citizens who support such norms should not be overly disappointed when the law only mildly condemns deviancy, given the potential of a morally equivocal regime to transmute into an unequivocally denunciatory one.

These insights, too, find support in our political experience. Those who favor abortion rights bitterly resist even largely symbolic antiabortion measures. Those who favor the right to bear firearms invest tremendous resources to block even the mildest forms of gun control. The "hard shoves/gentle nudges" theory vindicates their anxiety that these relatively inconsequential measures might soften public resistance to much more restrictive forms of regulation. Indeed, the sponsors of such laws, who promote them as vehemently as their adversaries oppose them, are no doubt banking on just this effect. 1993).

109 See Lawrence M. Friedman, Crime and Punishment in American History 127-40 (Basic 


\section{CONCLUSION}

My aim in this Article has been to present an account of how law and social norms interact. In particular, I have focused on what I call the "sticky norms problem"- the situation in which the reluctance of decisionmakers to repudiate a social norm makes them resist enforcement of a law intended to change that norm.

Whether such a norm is likely to yield or to remain stuck depends, I have argued, on how decisively the law expects the decisionmaker to repudiate it. Where the law embodies relatively mild condemnation of the norm, the desire of most decisionmakers to carry out their legal obligations is likely to dominate their personal commitment to the norm. The willingness of most decisionmakers to enforce will in turn create an environment in which the norm weakens, and in which decisionmakers therefore become willing to enforce progressively more condemnatory laws.

Where the law embodies a high degree of condemnation, in contrast, the aversion of most decisionmakers to renouncing their normative commitments is likely to trump their desire to carry out their legal obligations. The unwillingness of most decisionmakers to enforce will strengthen the norm, and thereafter even fewer decisionmakers will be willing to enforce the law.

Thus, sticky norms loosen in response to gentle nudges but stick in response to hard shoves. I have supported this thesis with a behaviorally and psychologically realistic model of individual and group decisionmaking, and with casual empirics relating to date rape, domestic violence, drugs, and various other forms of regulated conduct. I have also identified normative and prescriptive implications.

My analysis has been motivated by two objectives. One is to make the understanding of norm regulation more sophisticated. Norm scholars of an interventionist bent often assume that the best way to discourage objectionable behavior based on a social norm is to adopt a severely condemnatory law aimed at expressing the repudiation of that norm by society at large. Norm scholars of a conservative inclination, in contrast, tend to suggest that the self-conscious legal management of norms is futile. My argument suggests that both sides are wrong. Law is a powerful instrument for regulating even sticky norms, but the most effective regulatory strategy is moderate, not severe, condemnation.

The defense of moderation is in fact at the heart of my second motivating objective: the recovery of the progressive credentials of deterrence theory. "Deterrence" nowadays tends to be associated with repressive styles of criminal policymaking that see crackdown strate- 
gies as the appropriate solution to all manner of criminal wrongdoing. But the most theoretically elegant applications of deterrence-from the concept of wasted punishment to the concept of marginal deterrence to the concept of overdeterrence or chilling effect-have always involved showing how less can be more. Showing that less can be more was also the animating practical commitment of Bentham, Beccaria, and other classical deterrence theorists, who formulated deterrence theory as an intellectual counterweight to the mindless severity of the criminal law of their day.

I believe that deterrence theory is conceptually and rhetorically rich enough to underwrite a progressive critique of today's mindless severity as well. ${ }^{110}$ By showing that "gentle nudges" frequently dominate "hard shoves," I hope I have gone a small part of the way to showing that that is so.

110 See Dan M. Kahan, Between Economics and Sociology: The New Path of Deterrence, 95 Mich L Rev 2477 (1997). 


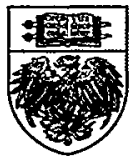

